\title{
PEMBERDAYAAN MASYARAKAT MELALUI PENGEMBANGAN INDUSTRI KERIPIK BONGGOL PISANG UNTUK MENINGKATKAN EKONOMI RUMAHAN DI DESA AIK BUKAQ
}

\author{
I Made Sudantha1, Nurmala dewi2, Aliza Tinur Awwali3, M. Rizky Ramadhan4, M. Mikrojul Ihsan5 \\ 1,2,3,4,5 Universitas Mataram, Mataram \\ ${ }^{*}$ Co-Author : tinuraliza@gmail.com
}

\begin{abstract}
ABSTRAK. Aik Bukaq merupakan salah satu desa yang memiliki sumber daya alam yang melimpah,mulai dari hasil pertanian sampai ke perikanan. Akan tetapi, kemampuan masyarakat dalam meemanfaatkan sumber daya alam nya masih kurang serta alat dan surat perijinan yang masih belum memadai. Tujuan program ini adalah pemberdayaan masyarakat melalui peningkatan produk olahan keripik bonggol pisang di Desa Aik Bukaq. Metode yang digunakan dalam program ini adalah pemberdayaan dan penyuluhan. Pengumpulan dan analisis data adalah dengan kajian pustaka dan metode observasi. Hasil yang dicapai dalam program ini adalah pengolahan keripik bonggol pisang dapat dikatakan layak dikembangkan sebagai usaha untuk meningkatkan pendapatan masyarakat. Dan didukung dengan adanya surat ijin usaha perdagangan serta pembaharuan kemasan.
\end{abstract}

Kata Kunci: Pemberdayaan masyarakat, Keripik, Bonggol Pisang

\begin{abstract}
Aik Bukaq is one of the villages that has abundant natural resources, ranging from agricultural products to fisheries. However, the ability of the community in the resource of natural resources is still lacking as well as tools and letters of licensing that are still not adequate. The purpose of this program is to empower people through the improvement of products processed by banana chips in the village of Aik Bukaq. The methods used in this program are empowerment and counseling. Data collection and analysis is with the study of libraries and observation methods. The results achieved in this program are processing chips of the banana cuffs can be said to be well developed as an effort to increase public income. And supported by the trading business license and package renewal..
\end{abstract}

Keyword: Community empowerment, chips, banana Bonggol

\section{PENDAHULUAN}

Pisang adalah komoditas buah tropika yang dicanangkan oleh Kementrian Riset dan Teknologi untuk dikembangkan di Indonesia yang didasarkan dengan pertimangan bahwa pisang merupakan komoditas berorientasi kerakyatan yang mampu meningkatkan kesejahteraan petani (Kasutjianingati dan Boer, 2013). Di desa Aik Bukaq, pohon pisang biasanya ditanam di pekarangan rumah ataupun di area perkebunan dan persawahan. Banyaknya tanaman pohon pisang di sekitar masyarakat ini belum bisa dimanfaatkan sepenuhnya, seperti apabila pisang sudah berbuah matang maka yang diambil hanya buahnya saja, bagian dari pohon yang lain dijadikan sebagai pakan ternak terutama pada bagian bonggol pisangnya. Kurangnya inisiatif masyarakat untuk membuat olahan yang lain menjadikan sumber daya masyarakat desa Aik Bukaq menjadi menurun. Oleh karena itu perlu adanya inisiatif untuk membuat produk olahan yang bahan dasarnya adalah bonggol pisang. 
Bonggol pisang memiliki nilai gizi yang tinngi yang sangat dibutuhkan oleh tubuh seperti kandungan karbohidrat nya yang termasuk ke dalam kompleks sedang cocok untuk menu diet, menurut Balitbang Pertanian (2008) karbohidrat buah pisang merupakan karbohidrat kompleks tingkat sedang dan tersedia secara bertahap sehingga penyediaan energinya tidak terlalu cepat, sedikit lebih lambat dari pada gula pasir dan sirup, tetapi lebih cepat daripada nasi, biskuit dan sejenis roti. Selain karbohidrat, bonggol pisang juga mengandung vitamin yang digunakan untuk membantu proses metabolisme tubuh. Menurut Wijaya (2013) vitamin A,B,dan C juga terdapat dalam buah pisang yang bermanfaat untuk membantu memperlancar sistem metabolism tubuh dan meningkatkan daya tahan tubuh dari radikal bebas, bonggol pisang mengandung gizi yang cukup tinggi dengan komposisi lengkap, dalam 100 gram bonggol pisang basah terkandung 43,0 kalori, 0,36 g protein, 11,60 g karbohidrat, 86,0 g air, beberapa mineral seperti $\mathrm{Ca}, \mathrm{P}$ dan Fe, Vitamin B1 dan $\mathrm{C}$, serta bebas kandungan lemak.

Salah satu aspek pengembangan bonggol pisang yaitu dengan cara membuat produk olahan keripik yang berbahan dasar bonggol pisang, dimana pisang yang digunakan yaitu pisang jenis puntik Sabe. Cara produksinya sangat sederhana dan masih menggunakan alat yang manual serta bahan- bahan yang digunakan sangat mudah didapatkan karena berada disekitar masyarakat. Sedangkan potensi pemasaran untuk keripik bonggol pisang sangat menjanjikan untuk dikembangkan karena sebagian orang belum mengetahui rasa dari keripik bonggol pisang ini. Selain itu, keripik bonggol pisang sangat bagus dijadikan produk olahan Karen dapat meningkatkan sumber daya manusia di desa Aik Bukaq dan tergolong baik dalam pemanfaatan sumber daya alam nya.

\section{ANALISIS PERMASALAHAN}

Aik Bukaq merupakan salah satu desa yang terletak di Kecamatan Batukliang Utara, Kabupaten Lombok Tengah, Provinsi Nusa Tenggara Barat, Indonesia. Sebagian besar penduduknya bersuku sasak dan menganut agama islam, Desa Aik Bukaq merupakan desa yang memiliki sumber daya alam yang melimpah, baik dalam bidang pertanian maupun dalam bidang perikanan. Desa ini juga memiliki pusat pariwisata yang masih aktif hingga saat ini. Potensi tersebut dapat dimaksimalkan jika didukung dengan sumber daya manusia yang mencukupi. Luas wilayah Desa Aik Bukaq secara keseluruhan adalah 756,62 Ha. Tanah sawah 283,00 Ha, Tanah kering 40,00 Ha, Tanah basah 7,09 Ha, Tanah perkebunan 385,19 Ha, Tanah lahan Pisang $55 \mathrm{Ha}$, Tanah fasilitas umum 33,34 Ha, Tanah hutan 8,00 Ha. Jumlah penduduk Desa Aik Bukaq 8.897 orang dengan pendidikan tertinggi S-2 dan 347 orang rata-rata berpendidikan SD. Desa Aik Bukaq memiliki komoditas yang begitu banyak, diantaranya pohon-pohon dan buah-buahan. Adapun pohon-pohon dan buah-buahan yang terdapat di Desa Aik Bukaq adalah pohon kelapa, pisang, mangga, alpukat, durian, dan nangka (Data desa Aik Bukaq, 2019). Namun, pemanfaatan pisang sebagai komoditas yang menguntungkan belum dilakukan.

\section{SOLUSI YANG DITAWARKAN}

Kegiatan ini dilaksanakan di Desa Aik Bukaq Kecamatan Batukliang Utara Kabupaten Lombok Tengah Nusa Tenggara Barat. Program ini dilaksanakan selama 45 hari, mulai dari tanggal 23 Desember 2019 sampai 06 Februari 2020. Untuk mencapai tujuan yang diharapkan, program KKN di desa Aik Bukaq, dilakukan dengan pemberdayaan masyarakat melalui pengembangan industri keripik bonggol pisang untuk meningkatkan ekonomi rumahan masyarakat desa Aik Bukaq. Pembagian jam kerja setiap program dilakukan secara adil, dimana untuk program utama di kerjakan 188 jam/orang dan setiap program kerja memiliki penanggung jawab masing-masing, sedangkan 
untuk program kerja tambahan dibagi menjadi 81 jam/orang dan memiliki penanggung jawab masing-masing. Dalam melaksanakan program kerja, mahasiswa didampingi oleh bapak Dosen Pembimbing Lapangan dan pemilik usaha keripik bonggol pisang yang bernama ibu Rusniwati. Metode analisis yang digunakan yaitu metode kajian pustaka dan observasi. Adapun prosedur pembuatan keripik bonggol pisang adalah sebagai berikut :

1. Bonggol pisang yang digunakan adalah pisang jenis pisang sabe yang sudah berbuah.

2. Bonggol pisang di bersihkan dan diambil inti nya, kemudian dipotong sesuai dengan ukuran yang diinginkan.

3. Setelah dipotong, bonggol pisang diiris tipis menggunakan pengiris keripik yang biasa digunakan.

4. Irisan bonggol pisang kemudian direndam menggunakan air kapur selama 2 jam.

5. Sementara menunggu irisan bonggol pisang direndam, dibuatkan adonan tepung sebagai campuran untuk keripik bonggol pisang. Adonan dibuat dengan komposisi sebagai berikut; tepung terigu, tepung tapioka, garam, dan air. Dan di aduk sampai tercampur semuanya.

6. Setelah irisan bonggol pisang direndam selama dua jam, irisan bonggol pisang ditiriskan dan kembali di rendam selama 10 menit menggunakan air panas.

7. Setelah itu, irisan bonggol pisang ditiriskan, dan di celupkan ke dalam adonan yang sudah dibuat tadi lalu di goring sampai berwarna coklat keemasan.

8. Setelah matang, keripik bonggol pisang ditiriskan kemudian dimasukkan ke dalam toples. Setelah dingin, keripik bonggol pisang ditambahkan penyedap rasa lalu dikemas dan siap dijual.

\section{HASIL DAN PEMBAHASAN}

Sumber daya manusia (SDM) merupakan salah satu faktor yang sangat penting dalam suatu perusahaan, Oleh karena itu, SDM harus dikelola dengan baik untuk meningkatkan efektifitas dan efesiensi suatu perusahaan. Sumber Daya Manusia di pedesaan harus lebih maju daripada perkotaan, karena pedesaan merupakan penopang ekonomi perkotaan. Jika SDM di pedesaan dibangun dan diorganisasi serta diberi pendidikan dan pelatihan yang baik maka desa tersebut dapat berkembang dengan pesat dan baik. Menurut Hasibuan (dalam Lucyana Trimo, dkk., 2017) menyatakan bahwa pengembangan SDM adalah suatu usaha untuk meningkatkan kemampuan teknis, teoritis, konseptual, dan moral sesuai dengan kebutuhan pekerjaan/jabatan melalui pendidikan dan latihan.

Masyarakat pedesaan kurang mempunyai kemampuan untuk memperoleh akses terhadap layanan-layanan dari pemerintah maupun swasta yang mayoritasnya berada di pusat kota. Sumber Daya Manusia yang unggul harus dapat dipertahankan secara berkelanjutan, untuk itu diperlukan suatu kebijakan dalam pemberdayaan budaya yang artinya dengan budaya, suatu perusahaan akan melahirkan kebersamaan pola pikir yang unggul sehingga memiliki komitmen dalam menjalankan peran yang ditugaskan kepadanya. Jadi pemberdayaan haruslah dipandang sebagai suatu cara yang amat praktis dan produktif untuk meningkatkan kualitas dan kuantitas dari SDM itu sendiri.

Program pemberdayaan masyarakat melalui pengembangan industri pengolahan keripik berbahan dasar bonggol pisang ini dilakukan secara terstruktur dan melibatkan masyarakat secara langsung. Kegiatan ini dilaksanakan bersama mitra serta remaja-remaji di Desa Aik Bukaq Kecamatan Batukliang Utara Kabupaten Lombok Tengah.

\section{Higienitas}

Higiene sanitasi adalah suatu upaya untuk menghindarkan diri dari penyakit. Secara definisi hygiene adalah usaha kesehatan preventif yang menitikberatkan pada kegiatan kebersihan individu dan kesehatan pribadi. Sedangkan sanitasi adalah pencegahan penyakit dengan cara mengatur 
faktor lingkungan yang berkaitan dengan transmisi penyakit (Naria,2015). Higiene sanitasi makanan dan minuman diperlukan untuk melindungi makanan dari kontaminasi maupun mikroorganisme penular penyakit.

Dalam program Higienitas, bahan-bahan yang digunakan dicek secara langsung keamanan dan kebersihannya. Peralatan yang dgunakan cukup memadai serta bahan-bahan pembuatan tergolong cukup bersih, Hal ini diketahui dari pengamatan secara langsung yaitu sebelum pembuatan peralatan dan bahan-bahan pembuatan keripik bonggol pisang dibersihkan terlebih dahulu. Pendataan alat dan bahan keripik bonggol pisang dapat dilihat pada Gambar 1 .

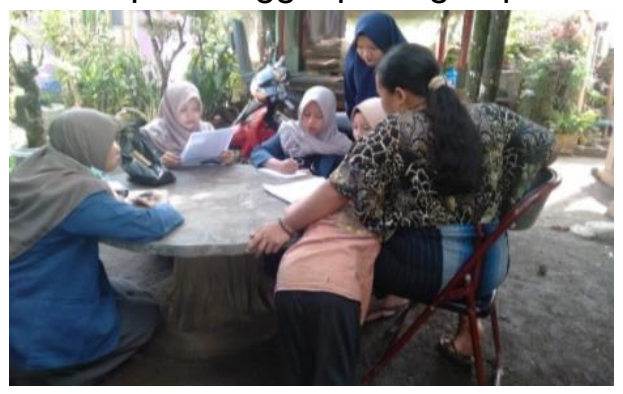

Gambar 1. Pendataan alat dan bahan keripik bonggol pisang

Bahan utama dari keripik ini adalah bonggol pisang jenis pisang sabe, dimana pisang yang digunakan yaitu pisang yang sudah berbuah sebelumnya. Apabila menggunakan pisang yang belum berbuah maka keripik akan terasa pekat dan kurang renyah. Bonggol pisang yang sudah diiris dapat dilihat pada Gambar 2.

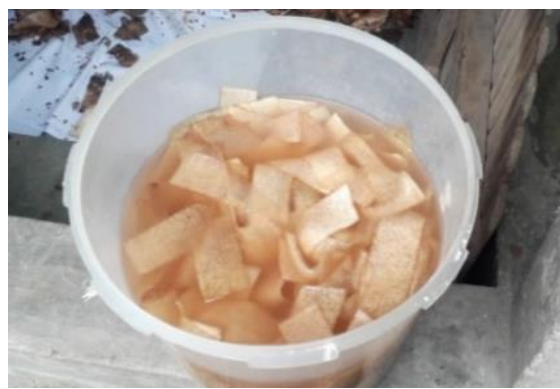

Gambar 2. Bahan utama keripik bonggol pisang.

Cara pembuatan bonggol pisang ini sangat sederhana, bonggol pisang yang sudah diiris kemudian direndam selama 2 jam menggunakan air kapur kemudian di cuci bersih dan ditiriskan, setelah itu direndam kembali dengan air panas selama 10 menit. Setelah itu ditirskan kemudian dicelupkan kedalam adonan yang berbahan tepung terigu, tepung tapioca, garam, dan air. Kemudian digoreng sampai berwarna coklat keemasan, setelah matang keripik bonggol pisang diangkat dan ditiriskan minyaknya. Setelah itu dimasukkan ke dalam toples dan ditambahkan penyedap rasa lalu dikemas dan siap dijual. Keripik bonggol pisang yang sudah dikemas dapat dilihat pada gambar 3 


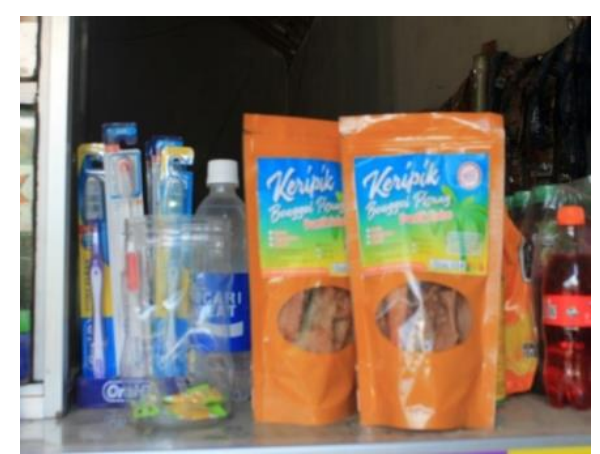

Gambar 3. Penjualan secara oflline dengan menitipkan di warung-warung.

\section{Surat Ijin Usaha}

Menurut Setianto (2008) dalam Setyaningrum dkk (2011) menyatakan bahwa setiap orang yang ingin mendirikian usaha perdagangan selalu mengantongi surat ijin dari pemerintah. Surat ijin tersebut diminta baik oleh perseorangan maupun badan hukum, hal ini dilakukan sebagai legitimasi dari perusahaan yang didirikan. Permohonan ijin mendirikan usaha ini tidak hanya bagi perusahan yang melakukan perdagangan lintas batas dan usaha yang berskala besar, tetapi juga bagi perusahaan regional dan berskala kecil.

Dalam usaha perdagangan yang melampaui batas daerah baik itu usaha besar atau usaha perdagangan kecil, SIUP (Surat ljin Usaha Perdagangan ) ini wajib diurus sebelum pengusaha melakukan kegiatannya. Tujuan memiliki surat ijin usaha perdagangan ini adalah agar usaha perdagangan mendapat legalisasi oleh pemerintah, sehingga tidak banyak mendapat masalah dikemudian hari. Adapun prosedur pembuatan surat ijin usaha ini yaitu dengan mendatangi kantor camat terlebih dahulu untuk mencari informasi terkait dengan surat ijin usaha. Kemudian pergi ke kantor Dinas Penanaman Modal dan Pelayanan Terpadu Satu Pintu Lombok Tengah untuk mendaftarkan mitra dan mengambil formulir. Dalam mengisi formulir terdapat syarat yaitu adanya persyaratan yang harus dilengkapi atas persetujuan dari Dinas Lingkungan Hidup Lombok Tengah. Dalam surat persetujuan tersebut ada syarat yang harus dimiliki oleh pemilik usaha yaitu keterangan usaha dari desa yang dibuat di Kantor Desa Aik Bukaq (Gambar 4). Setelah persyaratan dilengkapi dan disetujui oleh pihak Dinas Lingkungan Hidup, formulir diantarkan ke kantor Dinas Penanaman Modal dan Pelayanan Terpadu Satu Pintu (Gambar 5), setelah dua hari dari hari pendaftaran surat ijin usaha perdagangan diterbitkan (Gambar 6).

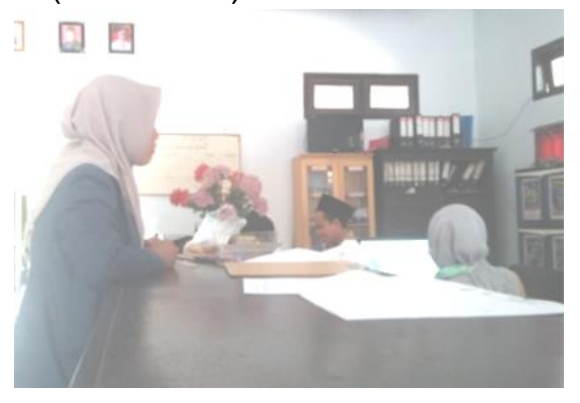

Gambar 4. Pembuatan surat keterangan usaha di kantor desa. 


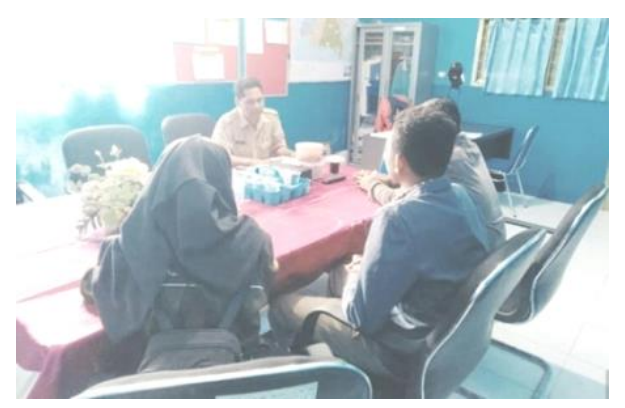

Gambar 5. Penyerahan syarat-syarat pembuatan Surat ljin Usaha di Dinas Penanaman Modal dan Pelayanan Terpadu Satu Pintu

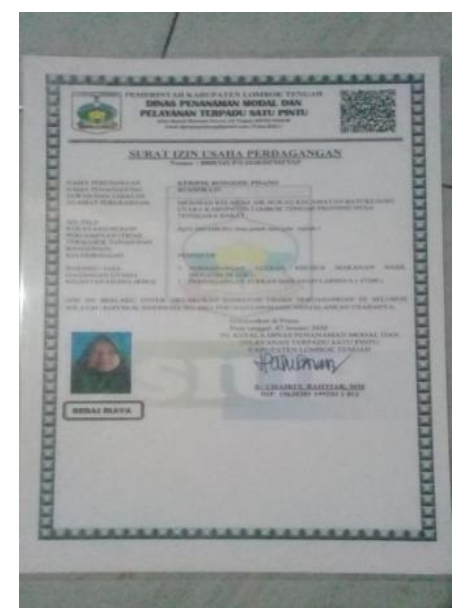

Gambar 6. Surat ljin Usaha Perdagangan

\section{Sertifikat BPOM dan Sertifikat Halal}

Dalam hal pemasaran, sertifikat BPOM dan Halal sangat dibutuhkan untuk kelengkapan dalam suatu usaha. Apabila suatu perusahaan makanan sudah memiliki sertifikat BPOM dan Halal, artinya makanan tersebut sudah teruji kebersihan maupun higienitas nya. Sebelum sampai ke tahap BPOM dan Halal, pemilik usaha terlebih dahulu harus memiliki surat ijin usaha yang dibuat sesuai dengan arahan dari kantor camat. Adapun prosedur untuk membuat sertifikat BPOM dan Halal yaitu dengan membuat surat ijin usaha di Dinas Penanaman Modal dan Pelayanan Terpadu Satu Pintu di Lombok Tengah, setelah itu melengkapi persyaratan yang diberikan oleh pihak Dinas Penanaman Modal dan Pelayanan Terpadu Satu Pintu. Selain surat ijin usaha, untuk mencapai BPOM dan Halal, pemilik usaha harus memiliki sertifikat SPP-IRT yang berguna untuk pembuatan sertifikat BPOM dan Halal.

Sebelum sertifikat SPP-IRT diterbitkan pihak dari Dinas Kesehatan melakukan penyuluhan terlebih dahulu terkait dengan keamanan pangan, tujuan dilakukannya penyuluhan ini adalah agar masyarakat mengetahui bagaimana cara mengolah makanan yang baik dan sehat. Setelah dilakukannya penyuluhan, pihak dari Dinas Kesehatan akan melakukan survey ke lokasi pembuatan keripik bonggol pisang, survey ini bertujuan untuk mengetahui dimana lokasi pembuatan dan penyimpanan baik itu bahan baku maupun keripik yang sudah jadi. Setelah dilakukan penyuluhan 
dan survey, maka sertifikat PKP (Pengolahan Keamanan Pangan) akan diterbitkan, fungsi dari sertifikat PKP ini adalah syarat untuk mendapatkan sertifikat SPP-IRT.

Sertfikat SPP-IRT dapat digunakan untuk mendaftar produk agar mendapat sertifikat halal. Akan tetapi,sertifikat halal bisa saja ditolak karena lokasi produksi, dan produk tidak sesuai dengan kriteria yang diinginkan. Oleh karena itu, dalam melakukan suatu usaha terutama dalam bidang makanan perlu diperhatikan kebersihan alat maupun bahan yang digunakan agar erhindar dari penyakit, menurut Yuliano dan Nurcholis (2015) makanan yang tidak diolah secara baik dapat menyebabkan beberapa penyakit bagi yang mengkonsumsinya, antara lain : diare, cholera, atau muntaber, keracunan makanan dan demam, langkah untuk mencegah hal tersebut adalah dengan mentaati seluruh standar higienis dan sanitasi yang ditetapkan. Makanan dikatakan baik dan sehat jika memenuhi beberapa faktor diantaranya adalah kelezatan, cita rasa, kandungan zat gizi dalam makanan, baik secara bakteriologis, kimia dan fisik (Cahyadi, 2008).

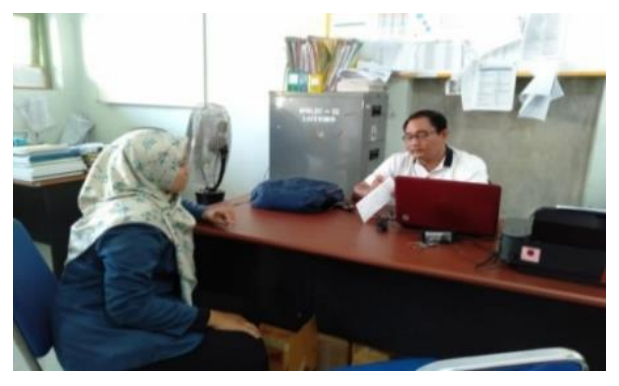

Gambar 7. Pengurusan administrasi penyuluhan kesehatan pangan di Dinas Kesehatan

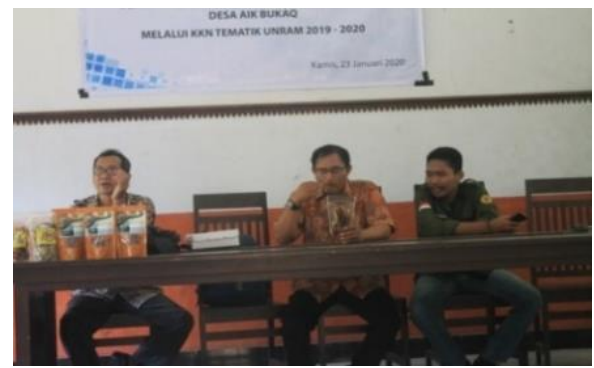

Gambar 8. Penyuluhan kesehatan pangan oleh Dinas Kesehatan

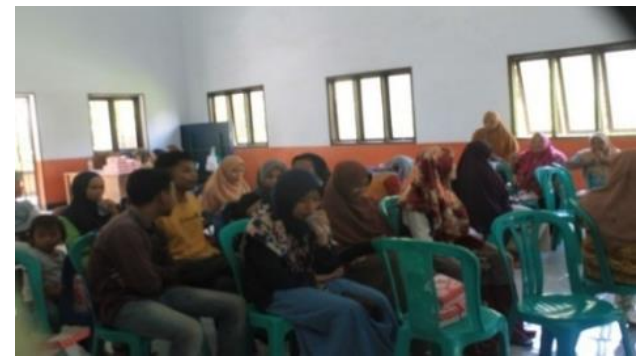

Gambar 9. Peserta penyuluhan adalah pengusahan industri rumahan di Desa Aik Bukaq 


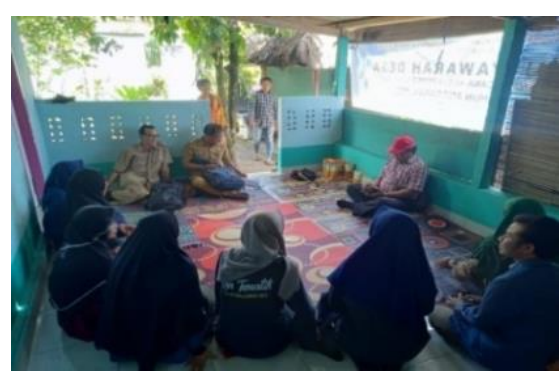

Gambar 10. Survey lokasi pembuatan keripik bonggol pisang oleh Dinas Kesehatan

Proses pembuatan bonggol pisang yang bertempat di Aik Bukaq masih diproduksi secara manual, yaitu masih menggunakan alat yang sederhana seperti pengiris keripik biasa. Keripik bonggol pisang ini terbuat dari bonggol pisang jenis puntik Sabe yang sudah berbuah, apabila pisang yang digunakan belum berbuah maka akan mempengaruhi kualitas keripik tersebut karena keripik menjadi pekat dan tidak renyah. Adapun metode pembuatannya adalah bonggol pisang yang sudah diambil intinya di potong sesuai dengan ukuran yang diinginkan,kemudian diiris tipis, tujuan diiris tipis adalah agar keripik cepat matang dan renyah. Setelah itu, irisan bonggol pisang dicuci bersih dan direndam menggunakan air kapur selama 2 jam. Sementara menunggu bonggol pisang yang direndam, adonan keripik bonggol pisang dibuat terlebih dahulu dengan komposisi sebagai berikut : tepung terigu, tepung tapioca, garam, dan air. Setelah 2 jam perendaman, bonggol pisang yang sudah diiris ditiriskan kemudian di rendam kembali dengan air panas selama 10 menit. Selanjutnya, dicelupkan ke dalam adonan yang sudah dibuat tadi dan digoreng sampai berwarna coklat keemasan. Setelah keripik bonggol pisang dingin dimasukkan kedalam toples dan ditambahkan penyedap rasa, kemudian dikemas dan siap untuk dipasarkan.

\section{Sertifikasi Merek}

Merek adalah bagian penting dalam pembuatan suatu produk. Merek digunakan sebagai nama produk dalam hal ini adalah Keripik Bonggol Pisang Puntik Sabe. Pengurusan sertifikasi merek dilakukan agar merek ini terdaftar sebagai suatu merek yang sah. Dalam mengurus sertifikat merek ini, dilakukan dengan mendatangi ruang HKI di LPPM Universitas Mataram (Gambar 11) untuk memperoleh informasi serta syarat-syarat yang diperlukan untuk membuat sertifikat merek. Salah satu hal yang dibutuhkan adalah membuat desain kemasan. Pembuatan dan pencetakan kemasan dilakukan di Rumah Kemasan. Setelah syarat dan desain kemasan disetujui, sertifikat merek dapat diperoleh.

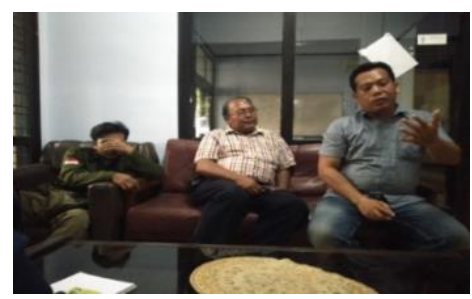

Gambar 11. Mencari informasi di HKI Universitas Mataram. 


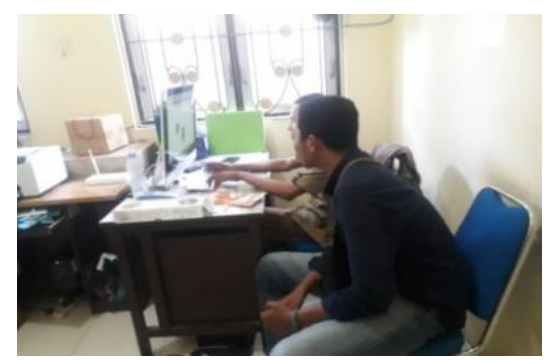

Gambar 12. Mendisain merek di Rumah Kemasan.

\section{Marketing}

Marketing merupakan salah satu kegiatan pokok setiap usaha yang dijalankan untuk mempertahankan kelangsungan hidup usahanya agar bisa terus berkembang dan bertahan untuk memperoleh laba atau untung sesuai dengan tujuan perusahaan baik usaha kecil, menengah, maupun perushaan besar sekalipun harus mampu menganalisis pluang pasar untuk melaksanakan strategi pemasaran produknya unuk mencapai visi dan misi perusahaan dan sesuai dengan perencanaan yang telah ditetapkan (Susilawati dan Yakin, 2017). Pemasaran keripik bonggol pisang dilakukan menggunakan dua metode,yakni; metode offline (yaitu secara langsung) dan online (promosi lewat media sosial). Untuk pemasaran secara langsung dilakukan di toko atau kios terdekat atau dapat langsung menghubungi kontak ibu Rusniwati (081909098308), sedangkan untuk pemasaran online nya dilakukan melalui media sosial dapat dilihat di akun @keripikbonggolpisangpuntiksabe (Gambar 13 dan 14).

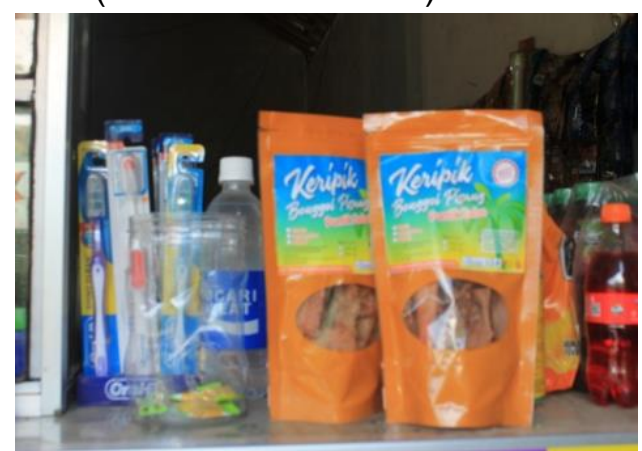

Gambar 13. Penjualan secara oflline dengan menitipkan di warung-warung.

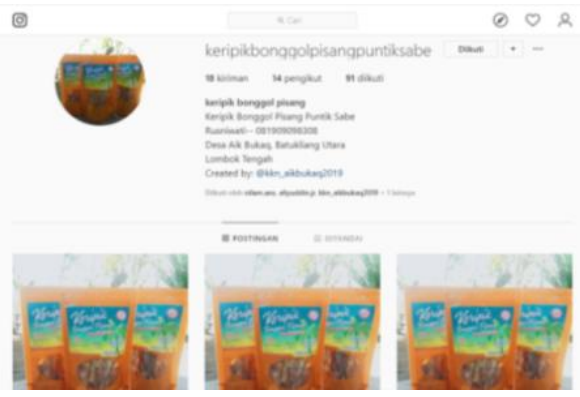

Gambar 14. Penjualan secara online dengan membentuk platform penjualan secara online.

Jika dilihat potensi bonggol pisang ini, sangat menjanjikan dalam suatu usaha, dikarenakan bahan yang digunakan mudah didapatkan karena berada di sekililing permukiman, sehingga memudahkan produsen untuk mendapatkan bahan baku nya. Selain itu, proses pembuatan nya juga tergolong mudah dan tidak menghabiskan banyak biaya. Apabila dikembangkan pemasaran sampai keluar daerah aik bukaq maka dapat menambah nilai ekonomi dari masyarakat setempat karena dari segelintir orang banyak yang tidak mengetahui keripik bonggol pisang ini. 
Oleh karena itu membantu dalam pembuatan surat ijin usaha sangat penting untuk dilakukan. Rata-rata pemilik usaha di desa Aik Bukaq belum memiliki surat ijin usaha sehingga pada saat pemasaran belum bisa dilakukan di luar daerah Aik Bukaq. Salah satu warga di Desa Aik Bukaq yaitu ibu Rusniwati, berhasil membuat produk keripik bonggol pisang sehingga saat ini bisa diproduksi dan dikembangkan sehingga dapat menambah penghasilan. Dalam sekali produksi diperoleh 150 bungkus keripik bonggol pisang siap jual dengan harga Rp. 5000/bungkus, keuntungan yang didapatkan dari penjualan keripik bonggol pisang ini adalah Rp. 360.000,00 dalam sekali produksi, dengan rincian modal awal produksi Rp. 390.000,00 dan hasil penjualan Rp. $750.000,00$. Adapun dampak yang diharapkan adalah adanya peningkatan pendapatan masyarakat sebagai akibat adanya usaha tambahan dari agroindustri berbasis potensi yang berskala rumah tangga.

Selain itu, hasil positif yang telah dicapai dalam pelaksanaan program ini, antara lain: (1) Meningkatnya kualitas hasil produksi. Jika sebelumnya produk olahan dari program ini berbentuk irisan tidak teratur, ketebalan tidak seragam, serta banyak yang sobek, kini bentuk irisan lebih teratur, ketebalan produk menjadi seragam, serta produk irisan yang sobek menurun drastis (2) Meningkatnya kapasitas produksi; (3) Pembaharuan kemasan menjadi lebih bagus dan rapi; (4) Terbitnya Surat ljin Usaha;(5) Peningkatan Pendapatan.

\section{KESIMPULAN}

Berdasarkan uraian diatas, maka dapat disimpulkan beberapa hal sebagai berikut:

a. Program utama yang telah dilaksanakan oleh mahasiswa KKN Tematik 2019/2020 yaitu Pemberdayaan Masyarakat Melalui Peningkatan Produk Olahan Keripik Bonggol Pisang.

b. Program utama KKN telah tercapai dengan rata-rata jam kerja perorang yaitu 188 jam/orang.

c. Mitra sudah mampu membuat keripik bonggol pisang sesuai dengan syarat kesehatan (higienitas), memperoleh surat izin usaha, pengurusan sertifikat halal, sertifikat BPOM, pengembangan pemasaran serta pembaharuan pada kemasan.

\section{REFERENSI}

Balitbang Pertanian. 2007. Prospek dan Arah Pengembangan. Agribisnis Pisang. Edisi kedua. Badan Penelitian dan Pengembangan Pertanian. Jakarta: Departemen Pertanian.

Cahyadi, 2008. Analisis dan aspek kesehatan bahan tambahan angan. Jakarta : PT Bumi Aksara

Hasibuan, M. S. P. 2002. Manajemen Sumber Daya Manusia. Ed. Revisi. Bumi Aksara, Jakarta.

Kasutjianingati., Boer, D. 2013. Mikropropagasi Pisang Mas Kirana (Musa acuminate L) memanfaatkan BAP dan NAA secara In Vitro. J. Agroteknos. 3(1)

Naria, E. 2015. Higiene Sanitasi Makanan dan Minuman Jajanan di Kompleks USU, Medan. Higiene Sanitasi Makanan dan Minuman Jajanan.

Setianto, A. Yudi. 2008. Panduan lengkap mengurus segala dokumen (perijinan, pribadi, keluarga, dan bisnis. Jakarta, Pranita Offset

Susilawati., Yakin, S. H. 2017. Analisis Strategi pemasaran makanan tradisonal (studi kasus industry rengginang di kecamatan sakra pusat). JPEK. Vol 1(1)

Wijaya, 2013. Manfaat buah asli indonsia. Jakarta: PT Gramedia

Yulianto, A. Nurcholis. 2015. Penerapan standard hygienes dan sanitasi dalam meningkatkan kualitas makanan di food dan beverage department @Hom Platinum Hotel Yogyakarta. Jurnal Khasanah IImu. Vol 6(2) 